\title{
ANALISIS DAN PERANCANGAN E-COMMERCE PADA TOKO SEPATU DOPE13STORE MENGGUNAKAN FRAMEWORK LARAVEL
}

\author{
Herdhani Eko Nugroho ${ }^{1)}$, Agung Nugroho ${ }^{2)}$ \\ 1) Sistem Informasi Universitas AMIKOM Yogyakarta \\ ${ }^{2)}$ Ilmu Komputer Sistem Informasi Universitas Amikom Yogyakarta \\ email : herdhani.nugroho@students.amikom.ac.id ${ }^{\text {l)}}$, agungnugroho@amikom.ac.id ${ }^{2}$
}

\begin{abstract}
Abstraksi
Dope13Store adalah sebuah toko sepatu yang beralamatkan di Taman Kuliner, Condongcatur, Sleman, Yogyakarta. Dope13Store menjual berbagai merk sepatu dengan gaya kasual, saat ini Dope13store mempromosikan dan menjual produk mereka hanya terbatas pada sosial media, cara yang sebenarnya tidak buruk namun kurang efektif dalam penyampaian informasi dan proses penjualannya. Konsumen harus bertanya langsung melalui WhatsApp untuk mengetahui informasi suatu produk yang akan mereka beli. Dengan proses penjualan yang masih menggunakan media social yang dirasa kurang efektif, maka diperlukan suatu sistem yang dapat membantu efektivitas dan efisien kerja dalam proses penyampaian informasi serta proses penjualannya. Dengan membangun website penjualan diharapkan dapat mempermudah pihak Dope13Store dalam melakukan pekerjaannya serta meningkatkan penjualan sepatu dan kepercayaan masyarakat untuk melakukan transaksi di Dope13Store. Website penjualan ini nantinya akan dikerjakan dengan menggunakan Framework Laravel untuk memaksimalkan penggunaan PHP dalam proses pengembangan websitenya. Dan untuk menangani pembayaran secara online dan terintegrasi, website ini nantinya akan menggunakan midtrans payment gateway dengan raja ongkir untuk membantu menghitung biaya pengirimannya.
\end{abstract}

\section{Kata Kunci :}

e-Commerce, laravel, website, payment, framework

\begin{abstract}
Dope13Store is a shoe store which is located at Taman Kuliner, Condongcatur, Sleman, Yogyakarta. Dope13Store sells various brands of shoes with casual style, currently dope13store promotes and sells their products only on social media, which is actually not bad but less effective in conveying information and the sales process. Consumers must ask directly through WhatsApp to find out information about a product they are going to buy. With the sales process that still uses social media which is considered less effective, a system is needed that can help the effectiveness and efficiency of work in the process of delivering information and the sales process. By building a sales website, it is hoped that it will make it easier for Dope13Store to carry out their work and increase shoe sales and public trust in conducting transactions at Dope13Store. This sales website will be done using the Laravel Framework to maximize the use of PHP in the website development process. And to handle online and integrated payments, this website will later use a midtrans payment gateway with Raja Shipping to help calculate the shipping costs.
\end{abstract}

Keywords :

e-Commerce, laravel, website, payment, framework

\section{Pendahuluan}

Dope13Store menjual berbagai merk sepatu dengan gaya kasual, saat ini Dope13Store mempromosikan dan menjual produk mereka hanya terbatas pada sosial media, cara yang sebenarnya tidak buruk namun kurang efektif dalam penyampaian informasi dan proses penjualannya. Media sosial yang digunakan Dope13Store hanya sebatas menampilkan foto dan deskripsi singkat produk, hal tersebut menyebabkan konsumen atau calon pembeli menggunakan media lain seperti WhatsApp untuk menanyakan informasi produk yang akan mereka beli. Masalah lain penggunaan media sosial sebagai media utama penjualan ialah dalam hal update data harus dilakukan disetiap satu kiriman yang ada, sosial media juga tidak dapat menampilkan kategori dari setiap produk, stok produk juga akan menjadi hal yang ditanyakan dari calon pembeli, serta rekap laporan yang dilakukan secara manual dapat beresiko lebih besar dan memakan waktu. Dengan memanfaatkan sistem penjualan melalui website calon pembeli dapat melihat detail informasi produk yang ditampilkan pada website, proses transaksi dan pencatatan transaksi yang ditangani oleh sistem membuat proses pelayanan yang lebih efisien serta pembelian barang tidak terbatas waktu dan tempat.

Ada beberapa referensi penelitian yang terdahulu yang kami gunakan sebagai pendukung dalam penelitian ini. Salah satunya dari penelitian tentang 
Website Domlabs. Website Domlabs telah berhasil dirancang dan dibangun menggunakan framework Codeigniter. Dengan website ini pelanggan dapat dengan mudah melihat koleksi produk, melakukan proses order yang terintegrasi dengan perhitungan ongkos kirim otomatis, konfirmasi pembayaran dan melihat riwayat order yang pernah dilakukan. Sedangkan bagi pemilik website adalah kemudahan dalam menajemen produk, order, stok, dan laporan penjualan[1].

Penelitian ini, akan membahas bagaimana membuat sebuah website e-commerce dengan Framework Laravel dengan studi kasus toko Dope13Store.[2] Electronic Commerce atau yang popular dikenal dengan E-Commerce adalah proses bisnis yang melibatkan perusahaan, konsumen, pedagang, services provider yang memanfaatkan jaringan internet, dan juga alat eloktronik yang mendukungnya[3].

Laravel adalah satu-satunya framework $P h p$ yang dapat memaksimalkan penggunaan $P h p$ di dalam proses pengembangan website. PHP menjadi bahasa pemrograman yang dinamis, tapi semenjak adanya Laravel, $P h p$ menjadi lebih powerful, cepat, aman, dan sederhana[4].

Untuk menangani pembayaran secara online dan terintegrasi, website ini nantinya akan menggunakan midtrans payment gateway dengan raja ongkir untuk membantu menghitung biaya pengirimannya. Midtrans merupakan platform payment gateway yang sudah membantu melayani pembayaran dari 8,800 pelaku bisnis online mulai dari skala start-up, growing business, hingga enterprise sekalipun.[5]. Raja Onkir sendiri adalah sebuah situs website yang memberikan informasi tentang biaya kirim barang keseluruh Indonesia. Ada beberapa kurir yang tersedia di situs Raja Ongkir, diantaranya : JNE, TIKI, POS Indonesia, ESL, PCP, dan RPX. Situs ini memberikan informasi ongkos atau biaya kirim dari berbagai daerah di Indonesia[6].

Dengan adanya website penjualan ini diharapkan dapat mempermudah pihak Dope13Store dalam melakukan pekerjaannya serta meningkatkan penjualan sepatu dengan menekan masalah pada pihak konsumen dalam membeli barang dan meningkatkan kepercayaan masyarakat melalui branding Dope13Store melalui website toko online ini.

\section{Metode Penelitian}

Alur penelitian yang digunakan bisa digambarkan pada gamabar 1 dibawah ini.

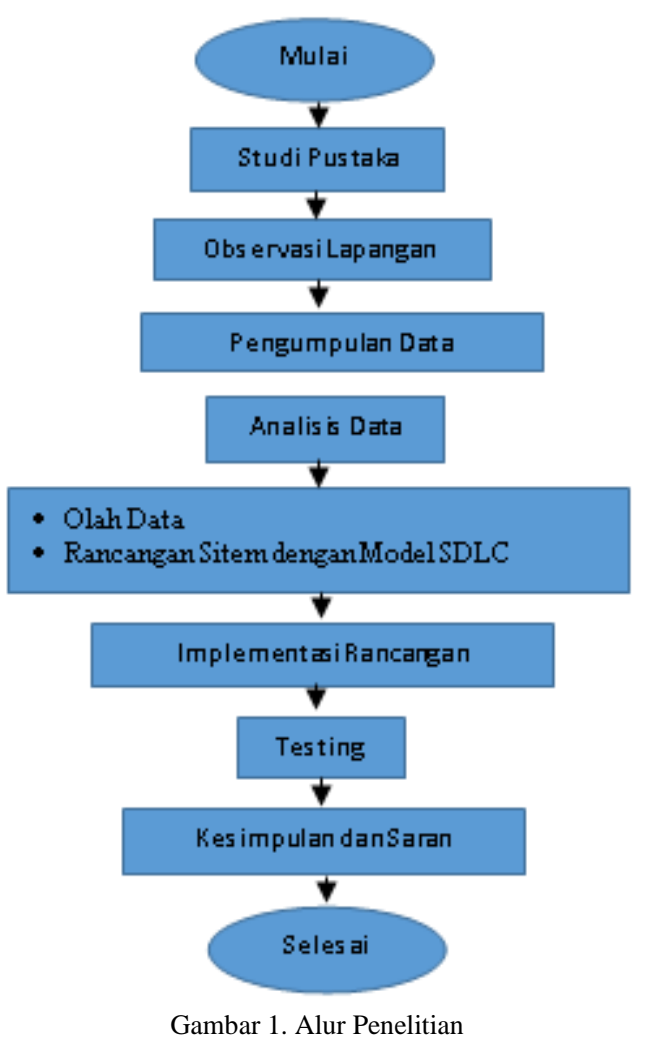

Dalam melaksakan kegiatan sesuai dengan alur penelitian yang ditunjukkan pada gamabar diatas. Agar setiap pelaksanaan kegiatan penelitian berjalan dengan lancar dan maksimal ada beberapa metode penelitian yang digunakan, diantaranya sebagai berikut.

1) Metode Pengumpulan Data

Metode yang akan digunakan dalam memperoleh data sebagai sumber informasi utama untuk mendukung keakuratan informasi yang ada. diambil menggunakan beberapa metode yaitu observasi dan wawancara.

2) Metode Analisis

Metode analisis yang digunakan didalam pembuatan sistem ini adalah analisis PIECES.

3) Metode Perancangan

Memodelkan perancangan database menggunakan Entity Relationship Diagram (ERD) dan memodelkan pembangunan sistem menggunakan UML (Unified Modelling Language).

4) Metode Pengembangan

Metode pengembangan pada penelitian ini mengacu pada sistem pengembangan SDLC (System Development Life Cycle) dengan menggunakan model waterfall.

5) Metode Pengujian

Metode pengujian pada penelitian ini menggunakan dua metode, yaitu : Black Box Testing yang merupakan merupakan pengujian yang berfokus pada kebutuhan 
fungsional sistem, kesesuaian alur dan fungsi hingga tampilan sistem, kemudian White Box Testing yang berfokus pada saat pengkodean program, variabel, fungsi, parameter yang ada pada program apakah terdapat kesalahan atau tidak[7].

\section{Hasil dan Pembahasan}

Dari hasil obserrvasi dan proses analisis di lapangan, menghasilkan tabel analis PIECES yang ditunjukakan pada tabel 1 . Selanjutnya dilakukan perancangan sistem menggunakan Unified Modeling Language (UML), perancangan Database menggunakan model Entity Relationship Diagram (ERD) dengan metode pengembangan SDLC (System Development Life Cycle). Untuk testing sendiri menggunakan White Box Testing dan Black Box Testing.

\subsection{Perancangan Sistem}

Model perancangan sistem website yang ada pada Dope13Store menggunakan Unified Modeling Language (UML). Berikut rancangan Use Case Diagram interaksi antara sistem yang akan dibangun dengan actor sistem pada website Dope13Store yang digambarkan pada gambar 2 dibawah ini.

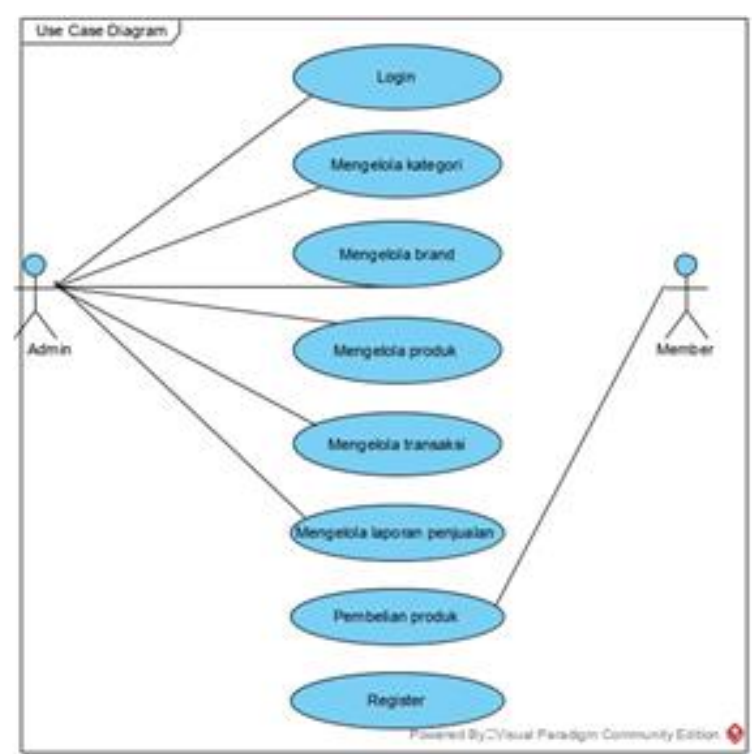

Gambar 2. Use Case Diagram

Langkah selanjutnya membuat class diagram yang mana nantinya didalam class diagram ini akan menggabarkan semua proses yang nantinya akan di implentasikan ke dalam sistem. Rancangan class diagram kebutuhan proses sistem website dope13store dituangkan pada gambar 3 class diagram proses sistem website dope13store.

TABEL 1 ANALISIS PIECES

\begin{tabular}{|c|c|c|}
\hline Parameter & Sistem Lama & Sistem Baru \\
\hline Performance & $\begin{array}{l}\text { Admin harus membalas pesan dari calon pembeli satu } \\
\text { persatu karena calon pembeli tidak bisa mendapatkan } \\
\text { informasi secara langsung tanpa bertanya ke admin } \\
\text { dahulu. } \\
\text { Calon pembeli harus menunggu balasan pesan dari admin } \\
\text { untuk informasi produk }\end{array}$ & $\begin{array}{l}\text { Admin tidak harus membalas satu persatu calon pembeli } \\
\text { lagi, karena semua informasi yang dibutuhkan calon pembeli } \\
\text { nantinya tersedia di website. } \\
\text { Calon pembeli dapat melihat informasi sepatu yang sudah } \\
\text { tersedia di website. }\end{array}$ \\
\hline Information & $\begin{array}{l}\text { Keterbatasan informasi yang ditulis secara manual dengan } \\
\text { media kertas. } \\
\text { Kesalahan manusia dalam penulisan informasi secara } \\
\text { menual. } \\
\text { Dalam mencari data lebih lama karena bertumpuknya } \\
\text { laporan yang ada sehingga akan memakan waktu lama. }\end{array}$ & $\begin{array}{l}\text { Informasi yang ditampilkan secara digital didalam website } \\
\text { dapat mempermudah mencari data. } \\
\text { Penulisan informasi berbasis digital akan sesuai dengan data } \\
\text { yang ada. } \\
\text { Data yang disimpan didalam database akan lebih rapi dan } \\
\text { lebih mudah diubah, dan dapat lebih cepat dicari. }\end{array}$ \\
\hline Economic & $\begin{array}{l}\text { Calon pembeli harus datang ke toko apabila akan } \\
\text { melakukan transaksi pembelian. }\end{array}$ & $\begin{array}{l}\text { Calon pembeli tidak harus datang ke toko untuk melakukan } \\
\text { transaksi pembelian sepatu. }\end{array}$ \\
\hline Control & $\begin{array}{l}\text { Kehilangan data akan lebih tinggi karena data disimpan } \\
\text { didalam satu komputer, dimana komputer ini dapat } \\
\text { digunakan oleh beberapa orang sekaligus. }\end{array}$ & $\begin{array}{l}\text { Setiap pengguna website memiliki akun masing - masing } \\
\text { sesuai dengan akses yang mereka miliki. }\end{array}$ \\
\hline efficiency & $\begin{array}{l}\text { Calon pembeli harus menempuh jarak yang ada dan harus } \\
\text { mengeluarkan uang bensin untuk sampai ke toko. }\end{array}$ & $\begin{array}{l}\text { Calon pembeli dapat melakukan transaksi melalui website } \\
\text { tanpa harus datang ke toko. }\end{array}$ \\
\hline Service & $\begin{array}{l}\text { Adanya jam operasional admin untuk membalas } \\
\text { pertanyaan informasi yang ditanyakan oleh calon } \\
\text { pembeli. }\end{array}$ & $\begin{array}{l}\text { Tidak ada jam operasional admin, karena informasi dapat } \\
\text { diakses kapanpun dan dimanapun asalkan terdapat koneksi } \\
\text { internet. }\end{array}$ \\
\hline
\end{tabular}




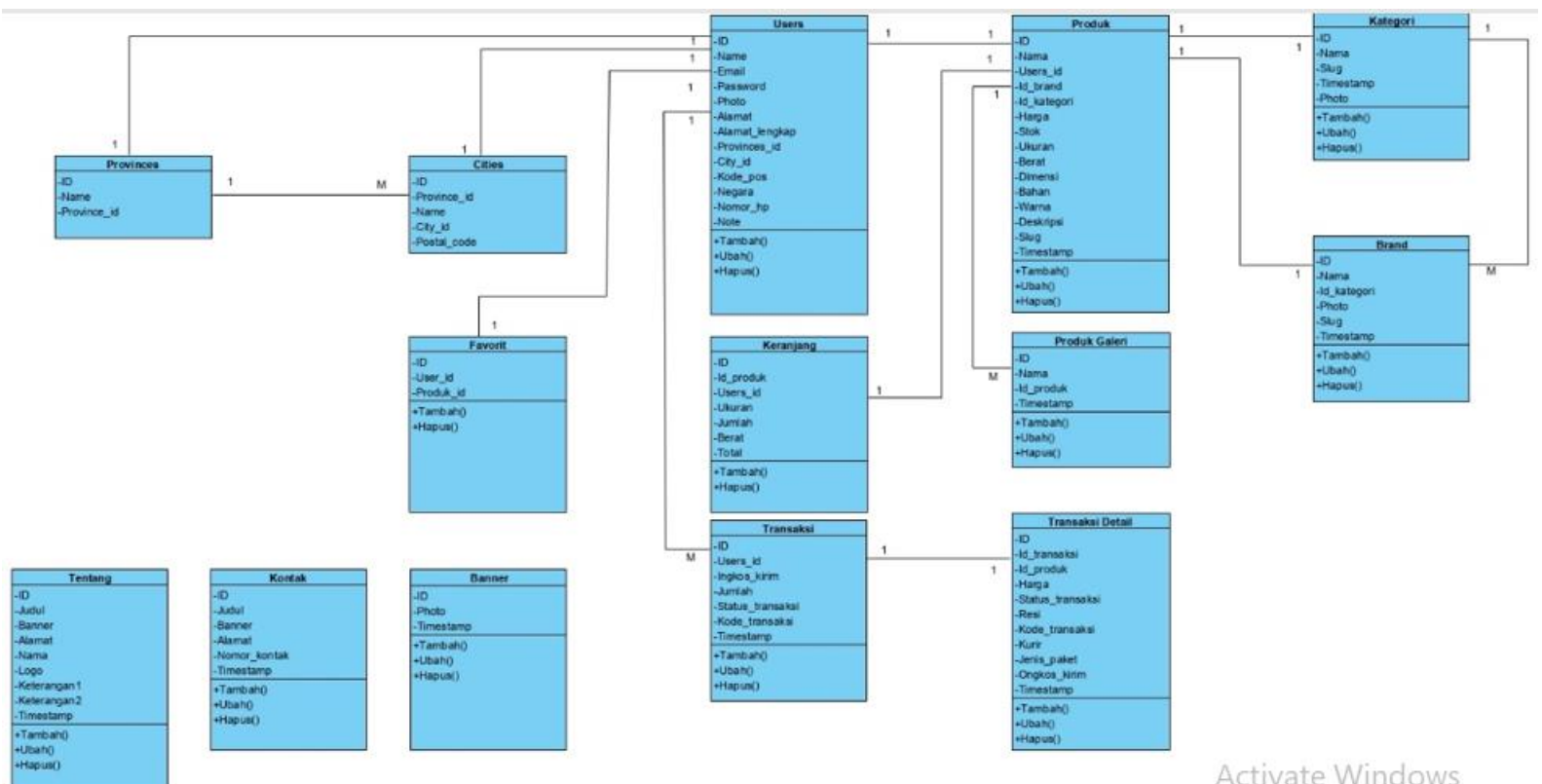

Gambar 3. Class Diagram Proses Sistem

\subsection{Perancangan Database}

Entity Relationship Diagram adalah diagram yang menggambarkan relasi antar tabel yang dilengkapi dengan entitas-entitasnya digunakan untuk merancang basis data. Rancangan ERD kebutuhan entitas dan atribut dari database yang akan dibuat, digambarkan pada gambar 4 dibawah ini.

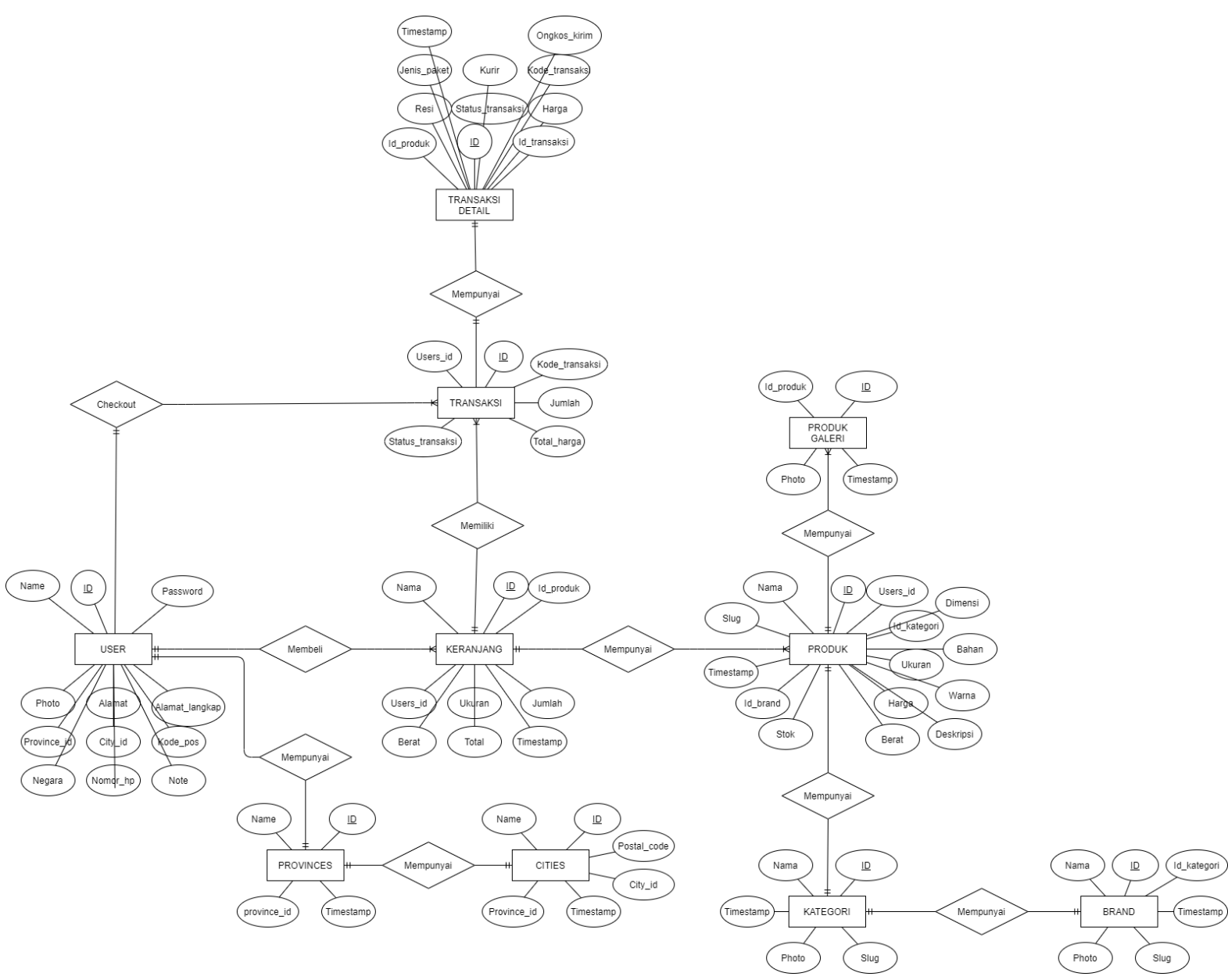

Gambar 4. Entity Relationship Diagram 


\subsection{Implementasi Interface}

Halaman home merupakan halaman utama didalam website ini, halaman yang akan tampil pertama ketika pengguna mengakses website. Di halaman ini pengguna akan menemukan banner yang merupakan slider, brand utama dan 8 produk terbaru yang ada didalam website, serta pilihan menu yang terdapat di paling atas website ini. Hasil Dari Implementasi rancangan desain halaman utama disajikan pada gamabar 5 berikut ini.

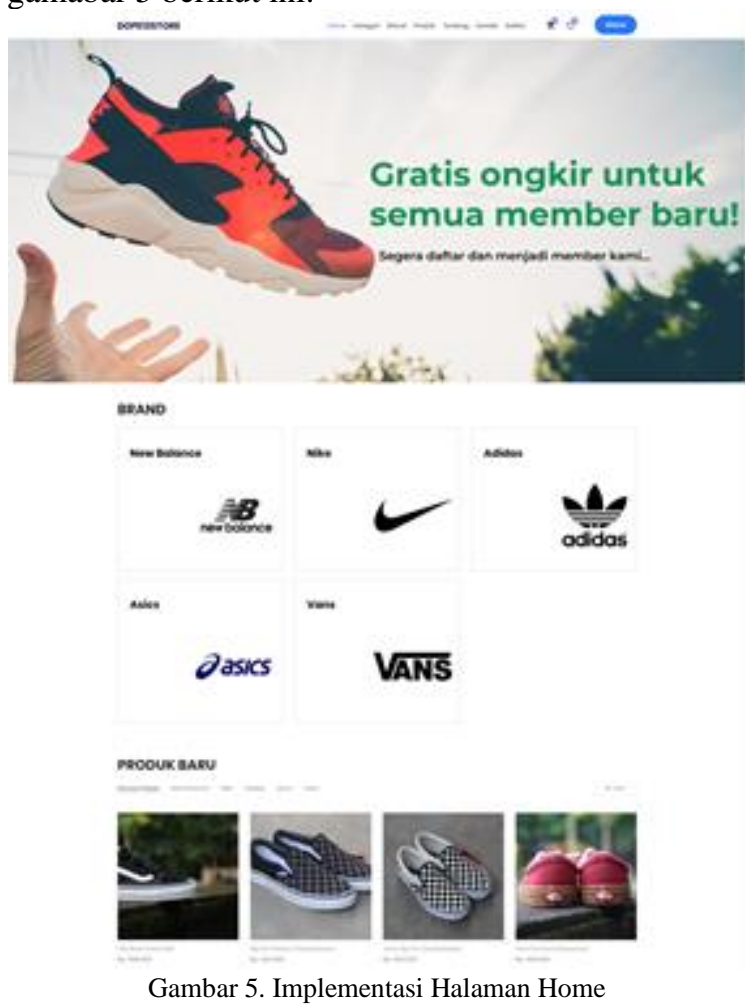

Halaman keranjang belanja merupakan halaman yang menampilkan produk - produk yang akan dibeli oleh pengguna, halaman ini juga menampilkan jumlah produk serta harga total belanja, dan pada bagian bawah menampilkan alamat pengiriman produk ke alamat pengguna. Berikut gambar 6 merupakan tampilan halaman keranjang.

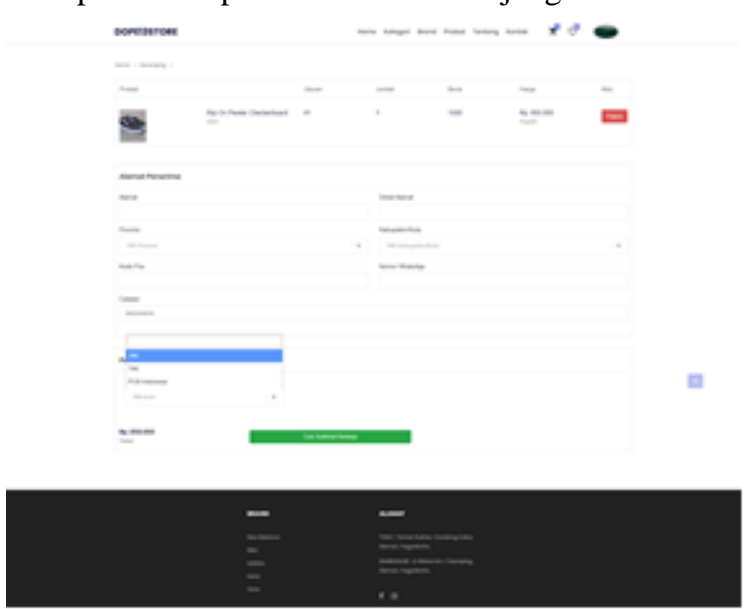

Gambar 6. Implementasi Halaman Keranjang
Halaman detail produk merupakan halaman yang menampung informasi secara lengkap suatu produk, seperti foto - foto produk, harga, berat, bahan, warna, ukuraan dan produk yang serupa dengan produk yang ditampilkan tersebut. Hasil Implementasi Rancangan halaman detail produk disajikan seperti pada gambar 7 berikut ini.

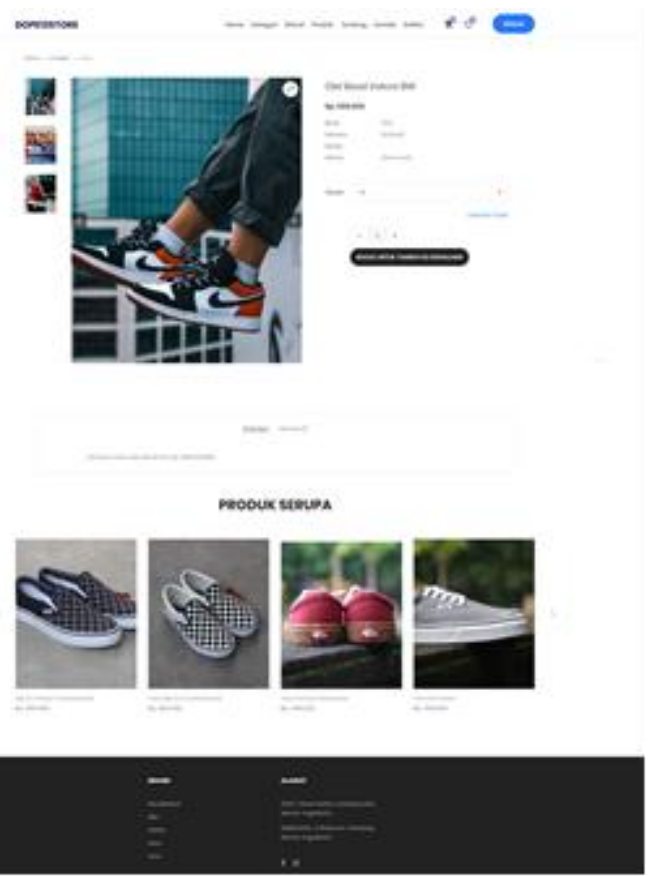

Gambar 7. Implementasi Halaman Detail Produk

\subsection{Testing Program}

Metode pengujian pada penelitian ini menggunakan dua metode, yaitu : Black Box Testing dan White Box Testing.

\subsubsection{White-box Testing}

1) Kesalahan Syntax

Kesalahan yang sering terjadi pada saat proses pengembangan sistem pada saat penulisan kode program yang biasanya tidak sesuai dengan aturan penulisan kode yang ada. Salah satu contoh kesalahan penulisan kode ini seperti ditunjukan pada gambar 8 dibawah ini.

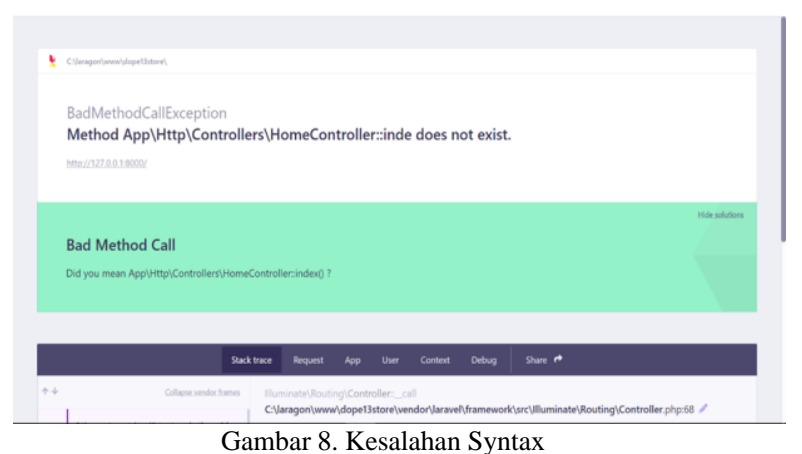


Dari contoh gambar 8 tersebut merupakan contoh kesalahan penulisan kode program pada saat pemanggilan function yang ada pada Controllers. Framework Laravel akan memberikan pesan error dalam bentuk interface seperti diatas dan memberikan informasi script yang terdapat kesalahan atau error pada bagian bawahnya yang memudahkan developer untuk menemukan error pada bagian tertentu yang mungkin terjadi.

2) Kesalahan proses

Kesalahan proses adalah kesalahan yang terjadi pada saat program berjalan dan terhenti pada saat tertentu, kesalahan ini terjadi apabila kode program tidak sesuai dengan algoritma sehingga program berhenti pada saat menjalankan proses tertentu.

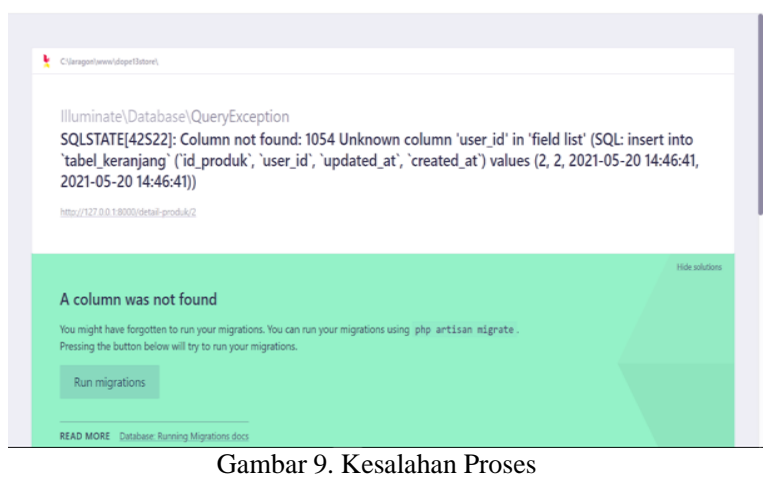

Pada gambar 9 diatas kesalahan yang terjadi pada saat member akan menambahkan produk ke keranjang belanja mereka, kesalahan ini terjadi karena data yang dikirmkan tidak memiliki sebuah kolom didalam sebuah tabel, maka sistem akan otomatis menampilkan error yang ada. Dan program berhenti pada saat proses simpan itu sendiri.

3) Kesalahan logika

Kesalahan logika adalah kesalahan yang terjadi pada program namun sistem akan tetap berjalan namun tidak sesuai dengan semestinya. Gamabr 10 dibawah ini adalah contoh kesalahan logika yang diuji pada website penjualan dope13store apabila member menambahkan produk ke keranjang dengan melebihi stok yang ada.

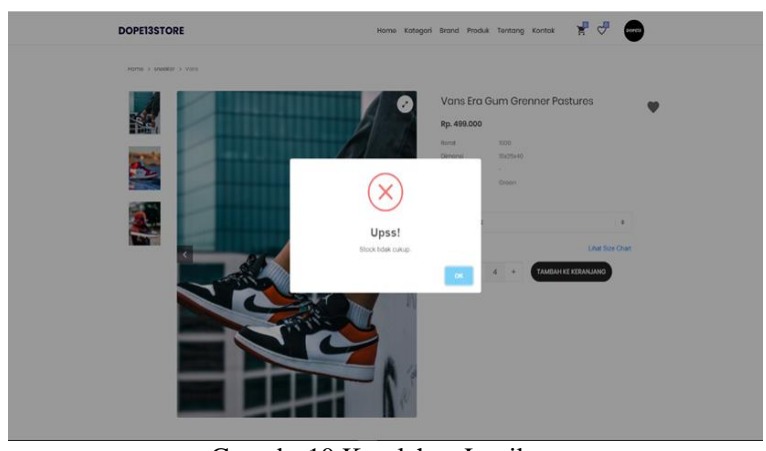

Gamabr 10 Kesalahan Logika

\subsubsection{Black-box Testing}

1) Pengujian Pada Member

Tabel dibawah ini merupakan tabel hasil pengujian black-box testing khusunya untuk member atau pengguna secara umum.
TABEL 2 PENGUJIAN BLACK-BOX TESTING

\begin{tabular}{|c|c|c|c|}
\hline No & Pengujian & Proses & Hasil \\
\hline 1 & Login member & Login & Berhasil \\
\hline 2 & $\begin{array}{l}\text { Menampilkan halaman } \\
\text { home }\end{array}$ & Index & Berhasil \\
\hline 3 & $\begin{array}{l}\text { Menampilkan halaman } \\
\text { kategori }\end{array}$ & Index & Berhasil \\
\hline 4 & $\begin{array}{l}\text { Menampilkan halaman } \\
\text { brand }\end{array}$ & Index & Berhasil \\
\hline 5 & $\begin{array}{l}\text { Menampilkan halaman } \\
\text { produk }\end{array}$ & Index & Berhasil \\
\hline 6 & $\begin{array}{l}\text { Menampilkan halaman } \\
\text { detail produk }\end{array}$ & Index & Berhasil \\
\hline 7 & $\begin{array}{l}\text { Melakukan pencarian } \\
\text { produk }\end{array}$ & Cari & Berhasil \\
\hline 8 & $\begin{array}{l}\text { Menambahkan produk } \\
\text { ke keranjang belanja }\end{array}$ & $\begin{array}{l}\text { Tambah } \\
\text { Keranjang }\end{array}$ & Berhasil \\
\hline 9 & $\begin{array}{l}\text { Menampilkan keranjang } \\
\text { belanja }\end{array}$ & Index & Berhasil \\
\hline 10 & $\begin{array}{l}\text { Mengubah keranjang } \\
\text { belanja }\end{array}$ & $\begin{array}{l}\text { Edit dan } \\
\text { Update }\end{array}$ & Berhasil \\
\hline 11 & $\begin{array}{l}\text { Menghapus keranjang } \\
\text { belanja }\end{array}$ & Destroy & Berhasil \\
\hline 12 & Menampilkan favorit & Index & Berhasil \\
\hline 13 & Menambah favorit & $\begin{array}{l}\text { Create } \\
\text { dan Store }\end{array}$ & Berhasil \\
\hline 14 & Menghapus favorit & Destroy & Berhasil \\
\hline 15 & Menampilkan profil & Index & Berhasil \\
\hline
\end{tabular}

2) Pengujian Pada Admin

Tabel dibawah ini merupakan tabel hasil pengujian black-box testing khusunya untuk administrator mengelola website.

TABEL 3 TABEL HASIL PENGUJIAN BLACK-BOX

\begin{tabular}{cllc}
\hline No & Pengujian & Proses & Hasil \\
\hline 1 & Login admin & Login & Berhasil \\
2 & $\begin{array}{l}\text { Menampilkan carousel } \\
\text { banners }\end{array}$ & Index & Berhasil \\
3 & $\begin{array}{l}\text { Menambah carousel } \\
\text { banners }\end{array}$ & $\begin{array}{l}\text { Create dan } \\
\text { Store }\end{array}$ & Berhasil \\
4 & $\begin{array}{l}\text { Menghapus carousel } \\
\text { banners }\end{array}$ & Destroy & Berhasil \\
5 & Menampilkan kategori & Index & Berhasil \\
6 & Menambah kategori & Create dan & Berhasil \\
& & Store & \\
7 & Mengubah kategori & Edit dan & Berhasil \\
& Update & \\
8 & Menghapus kategori & Destroy & Berhasil \\
9 & Menampilkan brand & Index & Berhasil \\
10 & Menambah brand & Create dan & Berhasil \\
& & Store & \\
11 & Mengubah brand & Edit dan & Berhasil \\
& & Update & \\
12 & Menghapus brand & Destroy & Berhasil \\
13 & Menampilkan produk & Index & Berhasil \\
14 & Menambah produk & Create dan & Berhasil \\
& & Store & \\
15 & Mengubah produk & Edit dan & Berhasil \\
& & Update & \\
\hline & & &
\end{tabular}

\section{Kesimpulan}

Berdasarkan hasil analisis, perancangan, dan implementasi sistem maka kesimpulan yang dapat diambil adalah sebagai berikut :

1) Proses bisnis dari implementasi sistem penjualan online berbasis website dapat berjalan dengan baik sesuai dengan testing yang penulis lakukan, meliputi black box testing dan white box testing. 
2) Sistem yang dibangun juga memiliki fitur untuk mengelola data kategori, brand, produk, transaksi dan mencetak laporan yang dibutuhkan pihak dope13store sendiri untuk mengetahui produk - produk yang mempunyai potensi lebih dan produk mana yang kurang diminati oleh pembeli.

3) Hasil dari penelitian ini merupakan satu website e-commerce pada toko sepatu dope13store sesuai dengan analisis dan perancangan, meliputi analisis pieces dan perancangan sistem menggunakan UML (Unified Modelling Language).

\section{Daftar Pustaka}

[1] Ibnu Dwi Lesmono, "Rancang Bangun Sistem Informasi Penjualan Sepatu Berbasis Website Dengan Metode Waterfall.", Vol.6 No.1, pp. 55 62, 2018.

[2] Ardyan Kusuma Putra dan Dony Ariyus, "Perancangan Sistem Informasi Toko Sepatu Domlabs Berbasis Website.”, 2019.

[3] Abdul Barkatullah, Hukum Transaksi Elektronik, Nusa Media, Bandung, 2017.

[4] Handika I.G, Purbasari.A, "Pemanfaatan Framework Laravel Dalam Pembangunan Aplikasi E-Travel Berbasis Website", Konferensi Nasional Sistem Informasi 2018, STMIK Atma Luhur Pangkalpinang.

[5] Midtrans. 2021. Midtrans Payments. Diakses 16 Desember 2020, dari https://midtrans.com/

[6] Raja Ongkir 2021, Rajanya Ongkos Kirim Terpadu, diakses pada tanggal 30 juni 2021. https://rajaongkir.com/dokumentasi,

[7] Hidayatullah, Priyanto, dan Jauhari Khairul Kawistara. 2017. Pemrograman WEB. Bandung. Informatika Bandung. 